サッカー育成年代の身体組成と下肢多関節動作で発揮されるパワーおよび スプリント能力の発育・発達特性

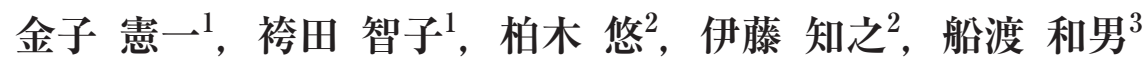

\title{
Developmental Characteristics of Body Composition and Lower-Leg Multi-Joint Power Outputs and Sprint Ability in Junior and Youth Soccer Players
}

\author{
Ken-ichi Kaneko ${ }^{1}$, Noriko Hakamada ${ }^{1}$, Yu Kashiwagi ${ }^{2}$, Tomoyuki Ito $^{2}$ and Kazuo Funato ${ }^{3}$ \\ ${ }^{1}$ 日本体育大学スポーツ・トレーニングセンター，７227-0033 神奈川県横浜市青葉区鴨志田町1221-1 (Sports Training \\ Center, Nippon Sport Science University, 1221-1 Kamoshida-cho, Aobaku, Yokohama, Kanagawa, 227-0033, Japan) \\ ${ }^{2}$ 日本体育大学大学院トレーニング科学系, =227-0033 神奈川県横浜市青葉区鴨志田町1221-1 (Graduate school of \\ Health and Sport Science, Nippon Sport Science University, 1221-1 Kamoshida-cho, Aobaku, Yokohama, Kanagawa, \\ 227-0033, Japan) \\ ${ }^{3}$ 日本体育大学, 干227-0033 神奈川県横浜市青葉区鴨志田町1221-1 (Nippon Sport Science University, 1221-1 Kamoshida- \\ cho, Aobaku, Yokohama, Kanagawa, 227-0033, Japan)
}

Received: October 11, 2011 / Accepted: December 19, 2011

\begin{abstract}
The purpose of this study was to investigate the cross-sectional development characteristics of body composition, lower-leg multi-joint power output and sprint running in nonelite junior and youth soccer players. The leg extension power, counter-movement vertical jump (CMJ), and 30m-sprint time for eighty male soccer players aged 13.8-18.1 yrs were measured. Junior and youth soccer players were compared with sedentary normal identical aged boys. Statistical analysis was used by one-way ANOVA and multiple comparisons of variance were performed on the basis of the Tukey-Kramer HSD test. Statistical significance was accepted at level of $\mathrm{p}<0.05$. Relative increases from 14 yrs to 18 yrs players were significantly $(\mathrm{p}<0.05)$ indicated; body height (7.7\%), leg extension power (87.8\%), CMJ (35.3\%), 30m-sprint (8.7\%). $10 \mathrm{~m}$-sprint time was negatively correlated with both leg extension power $(\mathrm{r}=-0.52)$ and CMJ $(\mathrm{r}=-0.60)$. Comparison of relative values of increase from 14 to $18 \mathrm{yrs}$ in junior and youth soccer players to those in sedentary normal boys were as follows; 2.3 (body height), 2.5 (leg extension power), 3.0 (CMJ), 2.1 (sprint ability). It might be suggested that consistent regular soccer training from junior and youth aged might prompt developmental gains not only largely for lower-leg multi-joint power but also not a little for sprint ability.
\end{abstract}

Jpn J Phys Fitness Sports Med, 61(2): 259-266 (2012)

Keywords : Soccer players, Cross-sectional developmental characteristics, Leg extension power, counter-movement vertical jump, Sprint running

\section{緒言}

サッカー選手の年齢による段階的指導においては， 8·9 歳を「プレゴールデンエイジ」 9 〜 12歳を, 「ゴー ルデンエイジ」と定義して，それぞれの育成方針が提示 されている1) (財団法人日本サッカー協会, 以下JFA). これらの年代での段階的な指導では, Scamonの発育発 達曲線 ${ }^{2}$ に示されるように，8歳から10歳前後に神経系 が筋力に比べ著しく発達することから, 技術の習得に最 も適した時期とされ，一方「ゴールデンエイジ」以降で は一般的に筋力や持久力が著しい発達を示すことから, サッカー選手に必要となる特異的な動きでの発揮パワー
やスキルの向上に主眼が置かれている。 JFA ${ }^{1)}$ では, 13 歳以降（中学生）の年代は，「ポストゴールデンエイジ」 または, ジュニアユースとも呼ばれ，16歳以降（高校生） からは,「インディペンデント・エイジ」または, ユー ス年代と呼ばれており，これらすべての年代をまとめて 「育成年代」と定義している。

形態発育と機能発達においてヒトの成長現象は並行し て進行するものではなく, 成長速度には必ず個人差があ るものの，身長や体重は男子で概ね14歳前後に増加率の ピークを迎える。さらに思春期発育スパートにおける身 長の最大の発育速度をPeak height velocity（PHV）と呼 び，筋力とパワーはこのPHV後に最大成長に到達する ${ }^{2)}$. 
育成年代と言われる日本のサッカー選手が筋カトレーニ ングやハイパワー系のトレーニングを開始するのは, 基 本的には高校 (ユース) に入学してからであり, このよ うなPHVが現れる中学生（ジュニアユース）年代では, 筋力トレーニングなどを行う習慣がないのが一般的であ る. また, サッカーのような集団スポーツの場合にはチー ム単位で活動することから，指導者がトレーニングや筋 カトレーニングを選手に指導する際, 生物学的な成熟度 を考慮した個別のトレーニングプログラムを提供するこ とは一般的には困難であり, 実際にはトレーニングの量 や質で調整しているのが現状であると考えられる。

サッカーの試合に打いて，ボールを保持していない状 況下での主な動作は, スプリント, 方向転換, ジャンプ などであり，これらの多くの動きでは素早い力の立ち 上がりを必要とする ${ }^{3)}$. 特に試合中の重要とされる局面 や，ゴールに直結する局面になるほど，より高い筋出力 や動きの加速能力が必要となると考えられる。シニアお よびジュニアのエリートサッカー選手を対象とした研究 では，単発的な筋出力と動きの加速能力が高いこと，お よび両者に高い相関関係が示されることが，競技力の高 いサッカー選手の特徵として報告されている ${ }^{4-8)}$. この ようなエリートサッカー選手の特徵である機能要素は, 子どもの頃のどの年代で培われる基本的能力なのであろ うか. つまり, サッカースクールやクラブ活動に参加す る競技レベルが低く, 育成年代となる中学, 高等学校の 生徒にもあてはまるか否かについては不明である。本研 究に掠いては, 下肢動作での単発な筋出力とスプリント 能力および両者の相関関係に関する横断的デー夕を取集 し, エリートサッカー選手の知見や一般の中学, 高等学 校の生徒の值と比較し, サッカー競技の育成年代に挍け る特徽と示すことにより, 選手育成に貢献することをね らいとした。 また, 下肢の単発的な筋収縮に打いて発揮 されるパワーや繰り返しの筋収縮において発揮されるス プリント能力は, 育成年代のうちにどのような推移を経 てどのくらい発達するかについてはこれまで示されてい ない. そのため, サッカーに重要とされる機能発達の増 加率を明らかにすることは, 選手を育成する立場の指導 者にとって, 選手の体力の現状を把握することができ, かつトレーニング指導の方向性を決定する上で非常に有 益な情報であると考えられる.

以上のことから, 本研究ではPHV後に筋力とパワー の最大成長が現れ, 形態発育において増加率のピークを 迎えることになる14歳から18歳までの育成年代の一般的 なサッカー選手を対象として, 身体組成と下肢多関節動 作で発揮されるパワーおよびスプリント能力を測定する ことにより, 形態面抢よび機能面の増加率を横断的に比 較することを目的とした．また，サッカー選手にとって ボールを蹴ったり，瞬時にジャンプをするといった単発
的な脚筋パワーは, 走動作のスプリント能力とパラレル に発達するものなのか否かを検討し, 育成年代の成長過 程の特徴を記述しょうと試みた.さらに,この年代のサッ カー選手と日頃スポーツを行っていない同年代の者との 間に, 形態発育や筋機能の発達傾向にどの程度の差があ るのかは不明であることから，日本人の体力標準值 II ${ }^{9)}$ による同世代の一般人男子のデー夕と比較し, 育成年代 に扔けるサッカー選手の形態発育と機能発達の増加率の 特徵を把握することを試みた。

\section{方法}

被験者 被験者は, 定期的にサッカーのトレーニング 及び試合を実施している14歳から18歳の男子ジュニア, ユースサッカー選手80名であった。被験者の身体的特徵 を表 1 に示した. 被験者の競技パフォーマンスレベルは, ジュニアユースのサッカークラブおよび国立，公立高校 のサッカー部に所属し, 選抜された経験のない選手を対 象とした，被験者掞よび保護者には，事前に文書にて実 験内容抢よび安全性について説明し, 書面にて同意を得 た。さらに被験者には測定前に, 測定の安全面と手順に ついて十分に説明をしてから実施した。な扮本研究は, 日本体育大学倫理委員会 (第010-H27号) の承認を得て 実施した。

\section{項目および測定方法}

身体組成 身体組成の計測は, Bod Pod (Body Composition System Mab-1000, Life Measurement Inc社製: 以下Bodpod）を用いた。肺容量についてはre-breathing により，5回の平均值より算出した。体重值, 肺容量, 全身の体積值より身体密度を求め, Brozekの式を用い て, 体脂肪率を算出した。

脚伸展パワー 脚伸展パワーの測定は, 油圧性等速性 レッグプレスマシン（T.K.K.1865 LEGPOWER，竹井機 器社製）を使用した。このマシンは，長座位姿勢に扔け る単発脚伸展パワーを測定する装置で, 実際のスポー ツ場面同様に, 多関節運動に扔ける脚伸展パワーの評 価をすることができる，測定では，レッグプレスマシ ンから出力される速度と力のアナログデータを, $\mathrm{AD}$ 変 換機（PowerLab, ADinstruments）を通し，パーソナ ルコンピュータに記録した。記録のサンプリング周波数 は1kHzとした。被験者は, レッグプレスマシンに座り, 両腕を胸の前で組んだ姿勢で計測を行なった。非伸縮性 のベルトを腰部に巻き, 膝関節 90 度の位置から, 股関節, 膝関節および足関節に扔いて最大伸展動作を行った。試 技は両脚 (両脚同時), 一側性（右脚，左脚）の順に試 技を 2 回行なった。設定速度は $1.0 \mathrm{~m} / \mathrm{s}$ とした。等速性筋 収縮条件とするため, 速度デー夕が一定となった区間を 平均值算出のための分析区間として平均パワー $(\overline{\mathrm{P}})$ を 
求めた

跳躍高（CMJ） 垂直跳び（以下CMJ）の測定には，床 反力計フォースプレート 9287B $(600 \mathrm{~mm} \times 900 \mathrm{mmKis-}$ tler社製Switzerland，以下FP）を使用した。被験者は 裸足でフォースプレートに乗り，両手を腰に置いた状態 のまま, 最大努力に扔いて反動動作を用いた両脚踏切 $\mathrm{CMJ}$ (カウンタームーヴメントジャンプ）を行った， 2 回の試技を行い, 記録の良い方を分析対象とした。跳躍 の高さは, 床反力データの滞空時間（t）ょり跳躍高を 算出した．跳躍高の算出式は以下の通りである.

Jump height $=1 / 8 \mathrm{gt}^{2}$

ここでの $\mathrm{t}$ は滞空時間 $(\mathrm{sec}), \mathrm{g}$ は重力加速度 $(9.81 \mathrm{~m}$. $\left.\sec ^{-2}\right)$ とした.

$30 \mathrm{~m}$ スプントタイム $30 \mathrm{~m}$ スプリントの測定には, レーザードップラー方式距離計測装置 (LDM 300C SPORT:JENOPTIK社製：以下Laveg）を用いた。距離 一時間データを, $1 \mathrm{~Hz}$ のローパスフィルター（4 次の バターワース型）を用いて平滑処理を行い， $5 \mathrm{~m}, 10 \mathrm{~m}$, 15m，20m，30mの通過タイムを算出した。計測はLaveg を三脚でほぼ被験者の腰の高さ（50～90 cm）に固定し， スタート地点より10m後方からカメラを構えた。 レンズ 内の計測焦点を被験者の腰椎部に合わせるように，検 者は熟練を積んだ，スタートの合図で $30 \mathrm{~m}$ 先までの全 力疾走を 2 回行ない, 記録の良い方を分析対象とした. Lavegでの距離の精度は, 算出は $0.5 \mathrm{~m} か ら 400 \mathrm{~m}$ までで測 定誤差は抢よそ $7 \mathrm{~cm}$ とされ，正確性は非常に優れてい

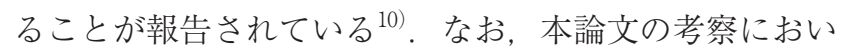
ては，根拠を示したうえで10mスプリントタイムと脚筋 出力との関係を求めた.

統計処理 各測定値はすべて平均值（Mean）士標準偏 差（SD）で示した。統計処理には, SAS社製の統計処 理ソフトJMPバージョン $8.0 を$ 用いて行った. 各測定值 と年齢群に打いて, 一元配置の分散分析を行った後に,
年代間による違いをTukey-kramerのHSD検定（多重比 較）を用いて検定した，全ての有意水準は危険率 $5 \%$ 以 内とした。 また，脚伸展パワーと跳躍高掞よびスプリン トタイムの関倸は, Pearsonの相関関係を用いた.

\section{結果}

身体組成 身長, 体重抢よび除脂肪量は, 年代が増すに 従い高くなる結果を示した.18歳と14歳の結果において 統計的上有意差が認められた $(\mathrm{p}<0.05)$ 。また, 17歳 と14歳の結果に扔いても統計上有意差 $(\mathrm{p}<0.05)$ が認 められた。除脂肪量（LBM）は, 体重と同様の傾向を 示した (表1).

脚伸展パワー 両脚および右脚で発揮される脚伸展パ ワーは，身体組成同様に年齢が増すに従い高い值を示 し，18歳と17歳の值は，14歳と15歳よりも有意に高い值 を示した $(\mathrm{p}<0.05)$. また, 対体重值においても，14 歳と15歳よりも有意に高い值を示した（ $\mathrm{p}<0.05 ） （$ 表 2 ).

CMJ 跳躍高は, 14歳と15歳では差はみられず, 16歳 以降, 年齢が増すに従い高い值を示し, 18歳と17歳は, 14歳と15歳および16歳と比較して有意に高い值を示した ( $<<0.05 ） （$ 表 2).

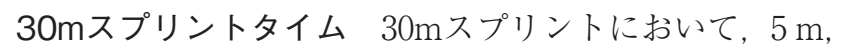
$10 \mathrm{~m}, 15 \mathrm{~m}, 30 \mathrm{~m}$ の各スプリントタイムは, 年齢が増す に従い夕イムが短縮する傾向が示されたものの, 16歳以 降に打いて, タイム差が生じにくくなる傾向が示され

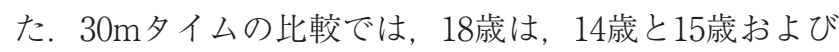
16歳と比較して有意に速い值を示した $(\mathrm{p}<0.05) .17$ 歳も14歳と15歳と比較して有意に速い值を示した（p< 0.05)。また, 16歳は14歳と比較して有意に速い值を示 した（p<0.05）（表 $3 ）$.

Table 1. Physical characteristics in each aged group. Significant differences $(p<0.05)$ compared to different aged groups as to $14 \operatorname{yrs}(\mathrm{a}), 15 \mathrm{yrs}(\mathrm{b}), 16 \mathrm{yrs}(\mathrm{c}), 17 \mathrm{yrs}(\mathrm{d})$ and 18yrs (e) were also indicated.

\begin{tabular}{lccccc}
\hline \multirow{2}{*}{ group } & \multirow{2}{*}{$\mathrm{n}$} & Age & Height & Weight & LBM \\
\cline { 2 - 6 } & & $(\mathrm{yrs})$ & $(\mathrm{cm})$ & $(\mathrm{kg})$ & $(\mathrm{kg})$ \\
\hline 14 & 9 & $14.2 \pm 0.3$ & $161.5 \pm 6.3^{\mathrm{cde}}$ & $52.0 \pm 5.3^{\mathrm{cde}}$ & $45.6 \pm 4.1^{\mathrm{cde}}$ \\
15 & 11 & $15.3 \pm 0.3$ & $166.9 \pm 5.0^{\mathrm{e}}$ & $54.9 \pm 6.5^{\mathrm{de}}$ & $49.3 \pm 5.8^{\mathrm{de}}$ \\
16 & 24 & $16.1 \pm 0.2$ & $168.3 \pm 4.2^{\mathrm{a}}$ & $57.4 \pm 4.9^{\mathrm{de}}$ & $52.6 \pm 4.1^{\mathrm{de}}$ \\
17 & 23 & $17.1 \pm 0.2$ & $171.9 \pm 6.3^{\mathrm{a}}$ & $62.5 \pm 5.9^{\mathrm{abc}}$ & $56.9 \pm 5.2^{\mathrm{abc}}$ \\
18 & 13 & $17.8 \pm 0.2$ & $173.9 \pm 5.7^{\mathrm{ab}}$ & $65.1 \pm 6.0^{\mathrm{abc}}$ & $60.1 \pm 5.7^{\mathrm{abc}}$ \\
\hline
\end{tabular}


Table 2. Leg power and CMJ in each aged group. Significant differences $(p<0.05)$ compared to different aged groups as to $14 \mathrm{yrs}(\mathrm{a}), 15 \mathrm{yrs}(\mathrm{b}), 16 \mathrm{yrs}(\mathrm{c}), 17 \mathrm{yrs}(\mathrm{d})$ and $18 \mathrm{yrs}(\mathrm{e})$ were also indicated.

\begin{tabular}{cccccc}
\hline \multirow{2}{*}{ group } & \multicolumn{2}{c}{ Leg Power $($ Bilateral $)$} & \multicolumn{2}{c}{ Leg Power $($ Right) } & \multicolumn{1}{c}{ CMJ } \\
\cline { 2 - 6 } & \multicolumn{1}{c}{$(\mathrm{W})$} & $(\mathrm{W} / \mathrm{kg})$ & $(\mathrm{W})$ & $(\mathrm{W} / \mathrm{kg})$ & $(\mathrm{cm})$ \\
\hline 14 & $688.3 \pm 235.9^{\text {cde }}$ & $13.2 \pm 4.1^{\text {cde }}$ & $481.2 \pm 77.9^{\mathrm{cde}}$ & $9.3 \pm 1.1^{\mathrm{cde}}$ & $32.1 \pm 3.4^{\mathrm{de}}$ \\
15 & $835.7 \pm 236.3^{\text {cde }}$ & $15.7 \pm 5.4^{\mathrm{e}}$ & $569.8 \pm 88.1^{\text {cde }}$ & $10.5 \pm 1.8^{\mathrm{de}}$ & $32.1 \pm 5.8^{\mathrm{de}}$ \\
16 & $1042.1 \pm 151.3^{\mathrm{be}}$ & $18.3 \pm 3.1^{\mathrm{a}}$ & $678.9 \pm 89.5^{\mathrm{bde}}$ & $11.9 \pm 1.5^{\mathrm{a}}$ & $36.8 \pm 4.7^{\mathrm{de}}$ \\
17 & $1195.6 \pm 186.6^{\mathrm{ab}}$ & $19.2 \pm 3.1^{\mathrm{a}}$ & $807.7 \pm 98.3^{\mathrm{abc}}$ & $13.0 \pm 1.6^{\mathrm{ab}}$ & $42.6 \pm 6.4^{\mathrm{abc}}$ \\
18 & $1292.7 \pm 175.2^{\mathrm{abc}}$ & $20.0 \pm 3.0^{\mathrm{ab}}$ & $852.6 \pm 85.8^{\mathrm{abc}}$ & $13.2 \pm 1.4^{\mathrm{ab}}$ & $43.5 \pm 6.1^{\mathrm{abc}}$ \\
\hline
\end{tabular}

Table 3. 30m-Sprint time as well as $5 \mathrm{~m}, 10 \mathrm{~m}$ and $15 \mathrm{~m}$ split times in each aged group. Significant differences $(\mathrm{p}<0.05)$ compared to different aged groups as to $14 \mathrm{yrs}(\mathrm{a}), 15 \mathrm{yrs}(\mathrm{b}), 16 \mathrm{yrs}(\mathrm{c}), 17 \mathrm{yrs}(\mathrm{d})$ and 18yrs $(\mathrm{e})$ were also indicated.

\begin{tabular}{ccccc}
\hline \multirow{2}{*}{ group } & \multicolumn{4}{c}{$30 \mathrm{~m}$-Sprint $(\mathrm{sec})$} \\
\cline { 2 - 5 } & $5 \mathrm{~m}$ & $10 \mathrm{~m}$ & $15 \mathrm{~m}$ & $30 \mathrm{~m}$ \\
\hline 14 & $1.34 \pm 0.07^{\mathrm{e}}$ & $2.13 \pm 0.08^{\mathrm{de}}$ & $2.84 \pm 0.10^{\mathrm{de}}$ & $4.87 \pm 0.17^{\mathrm{de}}$ \\
15 & $1.34 \pm 0.07^{\mathrm{e}}$ & $2.12 \pm 0.09^{\mathrm{de}}$ & $2.82 \pm 0.11^{\mathrm{de}}$ & $4.77 \pm 0.21^{\mathrm{de}}$ \\
16 & $1.30 \pm 0.06$ & $2.07 \pm 0.06^{\mathrm{e}}$ & $2.75 \pm 0.06^{\mathrm{e}}$ & $4.66 \pm 0.10^{\mathrm{ae}}$ \\
17 & $1.27 \pm 0.09$ & $2.03 \pm 0.09^{\mathrm{ab}}$ & $2.70 \pm 0.11^{\mathrm{ab}}$ & $4.57 \pm 0.15^{\mathrm{ab}}$ \\
18 & $1.23 \pm 0.13^{\mathrm{ab}}$ & $1.98 \pm 0.13^{\mathrm{abc}}$ & $2.64 \pm 0.13^{\mathrm{abc}}$ & $4.48 \pm 0.15^{\mathrm{abc}}$ \\
\hline
\end{tabular}

(A)

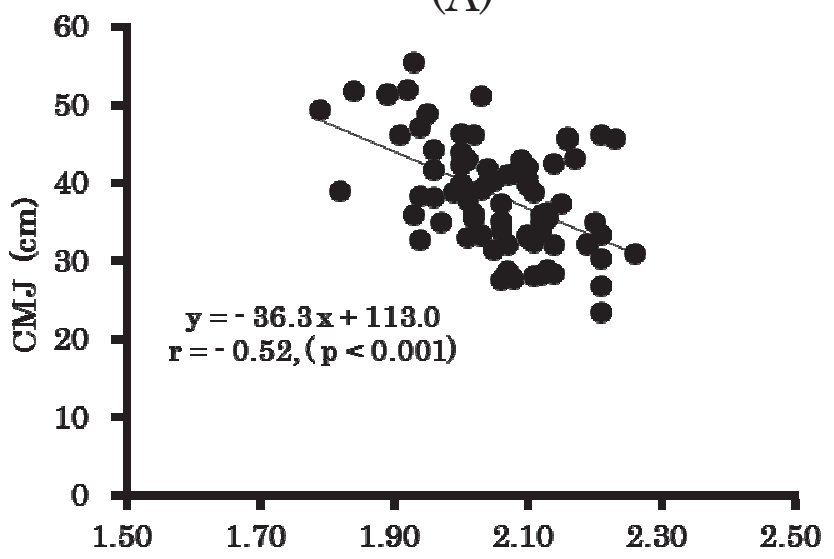

(B)

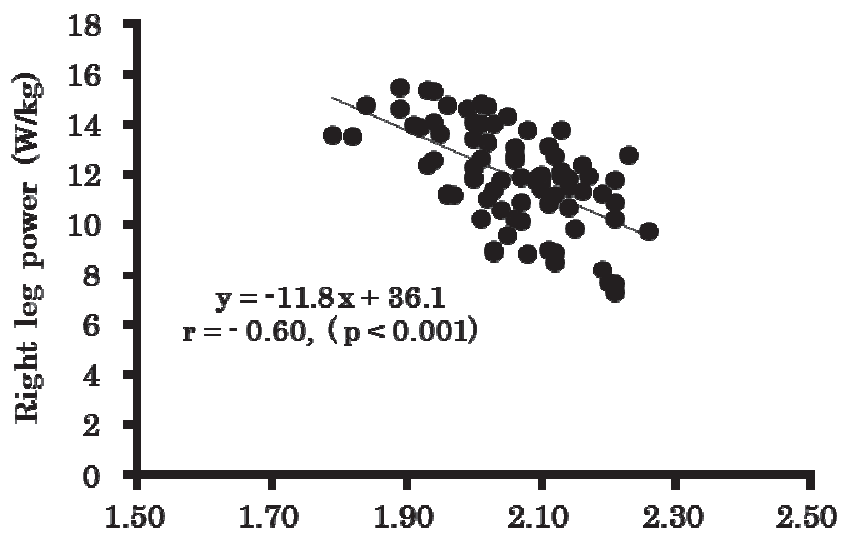

$10 \mathrm{~m}-$ Sprint (sec)

Fig 1. Correlation between 10m-Sprint time and CMJ (A), 10m-Sprint time and right leg power (B). 
スプリントタイムと跳躍高および脚伸展パワーの関係 全被験者を対象とした $10 \mathrm{~m}$ スプリントタイムと跳躍高お よび脚伸展パワーの間には，それぞれ有意な負の相関関 係が認められた（跳躍高, 図 $1 \mathrm{~A}: \mathrm{r}=-0.52, \mathrm{p}<0.001$, 右脚伸展パワー, 図 $1 \mathrm{~B}: \mathrm{r}=-0.60, \mathrm{p}<0.001)$.

\section{考察}

下肢筋出カとスプリント能力の機能発達 サッカー選手 の脚の筋出力や跳躍力およびスプリント能力は, 競技レ ベルの高い選手ほど高いとされる ${ }^{8,11-15)}$.さらに，競技 レベルの高い選手ほど, より動きの加速能力に優れかつ 試合中のスプリント回数が多く3,16)，プレー中のスプリ ントの $49 \%$ が $10 \mathrm{~m}$ 以下の短い距離であるとされる ${ }^{17)}$. 本

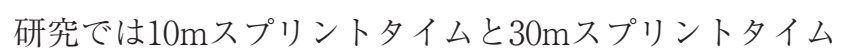
の間に有意な相関関係 $(\mathrm{r}=0.91, \mathrm{p}<0.001)$ が示され た.また, 10mスプリントの歩数は 14〜 15歳では8９ 歩, 16歳〜 18歳は $6 〜 8$ 歩を示したことから, 年齢とと もにストライドが大きくなることが示された，本研究の 10m夕イムは, 14歳で2.13秒, 18歳で1.98秒であり, こ れらの結果は, JFA ${ }^{18)}$ による同年代の日本代表選手(14 歳: 1.86秒, 18歳 : 1.83秒) や安松ら ${ }^{19)}$ (日本代表 : 1.745 秒，ドイツプロ選手：1.680秒）の成人の各国の代表選 手の結果と比較して遅い夕イムであった。一方本研究の 跳躍高の結果は，14歳で $32.1 \mathrm{~cm}, 18$ 歳で $43.5 \mathrm{~cm}$ であっ

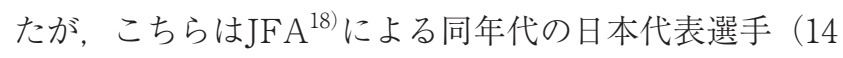
歳 : $36.6 \mathrm{~cm}, 18$ 歳 : $39.6 \mathrm{~cm})$ よりも, 18歳では本研究 の結果が高い值を示した。跳躍高は下肢の瞬発力（パ ワー）の指標として用いられ, 跳躍高とサッカーの競技 レベルとの間には相関関係があることはこれまでに報告 されている6). 本研究においても, 図 1 (A) で示した通 り，10mまでのスプリントタイムと跳躍高との相関関係 $(\mathrm{r}=-0.52, \mathrm{p}<0.001)$ が認められた。 また図 1 (B) で 示したように $10 \mathrm{~m}$ スプリントタイムと片脚での脚伸展パ ワーにおいても相関関係 $(r=-0.60, \mathrm{p}<0.001)$ が認め られた。これらのことから，14歳から18歳までの育成年 代のサッカー選手において, 年代に関係なくサッカーの プレー中のスプリントにおいて重要とされる10mまでの 加速局面に打ける 6 ～9歩の全力 “ダッシュ” 能力に優 れる選手は, 単発での脚による筋出力発揮能力も優れて いると推察される。 中屋敷 ${ }^{20)}$ は大学サッカー選手に対し て, バウンディング各種を適宜組み合わせ, 片脚ずつの 跳躍トレーニングを 4 カ月実施した結果, 疾走タイムと 跳躍力の向上がみられ, 片脚ずつの跳躍トレーニングが 疾走技術改善とパワー強化に有効な手段であると報告し ている。両脚での脚伸展パワーについて船渡ら ${ }^{21,22)}$ は, 12歳から60歳までの男子 1551 人, 女子498人を測定して いる。それによると, 男子では平均 $1220 \mathrm{~W}$, 女子では, 平均 $690 \mathrm{~W}$ であり, 女子の場合, 12歳から20歳までのパ
ワーの発達は，15歳で達成される傾向を示したものの, 男子では，思春期から急激なパワー発達がみられたとし ている、本研究の等速性での速度規定 $(1.0 \mathrm{~m} /$ 秒) 条件 による船渡ら ${ }^{21,22)}$ との值を比較すると, 年代が増すに従 いパワーの発達傾向がみられ, 絶対值では, 本研究の18 歳のサッカー選手がやや高い結果を示した。

14歳を基準とした相対的発育量の比較 図 2 には, 14 歳の各測定項目の值を $100 \%$ とた場合の各年代の相対 的増加量を示した。1歳の身長と $30 \mathrm{~m}$ スプリントの平均 速度は15歳から18歳までにほぼ同じ増加率を示し，18歳 では，身長が7.7\%，30mスプリントの平均速度では8.7\% の増加率であった。一方，18歳の除脂肪量は約 $31.6 \%$ の 増加率を示し, 年齢が増すに従い増加した。全身の骨格 筋量を反映する除脂肪量に関しては，Scamonの発育発 達曲線におけるホルモン分泌に関係する生殖型の発育が 著しい14歳から20歳にかけて最も増加し20歳以降で成人 值に達する ${ }^{23)}$. また, 単位弾面積当たりの筋力の増加速 度は, 13 から14歳付近が最も高いとされる ${ }^{21)}$. 脚伸展パ ワーの絶対值は，15歳は21.4\%，16歳で51.4\%，17歳で 73.7\%, 18歳で87.8\%と, 高い増加率を示した. しかしな がら, 対体重值では, 15歳は18.9\%, 16歳は38.7\%, 17 歳で45.8\%, 18歳は51.7\%の増加率を示し, 絶対值よりも 低くなる傾向が示された，跳躍高は，14歳，15歳では変 化はみられず, その後, 16歳で14.6\%, 17歳で32.4\%, 18 歳で $35.3 \%$ と 17 歳以降に急に増加することが示された. このように単発のパワー発揮能力である下肢筋出力の発 達は体重 (除脂肪量) が増すに従い発達する傾向がみら れる一方で, スプリント能力の15歳以降の増加率は低く, 身長の増加率と並行していることが示された。

図 3 には, 日本人の体力標準值 $\mathbb{I}^{9)}$ から14歳の值を 100\%として増加率に改編した相対発育の変化を示した。 同世代の一般人男子の身長と $50 \mathrm{~m}$ の平均速度の増加率 は, 図 2 で示したサッカー選手と同様, 他の機能の増加 率よりも低い值を示した。しかし, 身長の増加率につい て同世代の一般人男子と（本研究でのサッカー選手, 眓 2 からの值）を比較してみると，15歳で1.8\% (3.3\%), 16歳で2.7\% (4.8\%), 17歳で3.3\% (6.4\%), 18歳で3.4\%(7.7\%) となり, サッカー選手が同世代の一般人男子と比較して 14歳からの平均身長の増加率において2.3倍高い值を示 した。また, サッカー選手の下肢筋出力において, 脚伸 展パワーは, 18歳まで87.8\%（図 2 ）の増加率を示した のに対し，同世代一般人男子の脚筋力の増加率は $35.1 \%$ であり（図 3 ），サッカー選手が2.5倍高い值であった。 さらに, サッカー選手の跳躍高は18歳で $35.3 \% の$ 増加率 を示したが (図 2), 同世代の一般人男子の跳躍高の増 加率は $11.6 \%$ (図 3 ) と, サッカー選手が 3 倍高い值であっ た。これらのことから, 育成年代のサッカー選手は, 日 


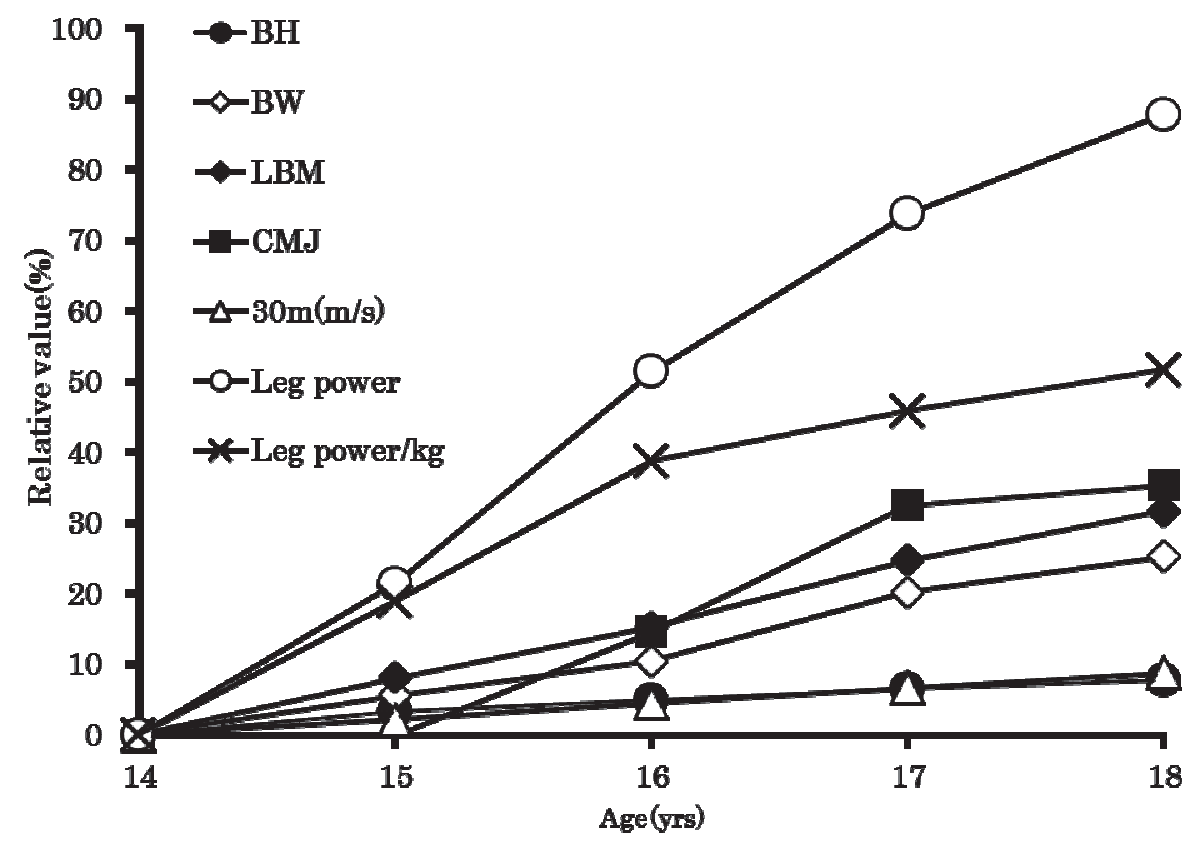

Fig 2. Relative values of development based on the values of 14 yrs as $100 \%$ for body composition, CMJ, 30m-sprint and leg power in soccer players.

(BH : Body Height, BW : Body Weight, LBM : Lean Body Mass, CMJ : Countermovement Vertical Jump, 30m(m/s): 30m-Sprint Velocity, Leg Power : Bilateral Leg Power, Leg Power / kg : Bilateral Leg Power /kg)

頃のトレーニングによって獲得した下肢多関節動作で発 揮されるパワーの発達に扔いては, 除脂肪量の増加とと もに高い増加率を示し, 同世代の一般人男子と比較して 大きな増加率を示した。 また，同世代の一般人男子 $50 \mathrm{~m}$ 走速度の18歳の増加率は4.1\%, 一方本研究のサッカー選 手 $30 \mathrm{~m}$ 走速度の18歳の増加率は $8.7 \%$ となり, 他の項目と 比較して増加率は低いものの, サッカー選手が2.1倍高 い值を示した。

サッカー育成年代選手におけるトレーニングの指針 14 歳から18歳までの増加率は, 身長ではサッカー選手が 7.7\%（同世代の一般人男子は $3.4 \%$ ), 平均走速度ではサッ カー選手が $8.7 \%$ （同世代の一般人男子は4.1\%）であっ たのに対し, 下肢筋出力に扔いては, 脚伸展パワーが 87.8\% (同世代の一般人男子は $35.1 \%$ ), 跳躍高は $35.3 \%$ (同 世代の一般人男子は $11.6 \%)$ であった。このように, 14 歳以降のサッカー選手のトレーナビリテイは, 特に脚伸 展パワーや跳躍高のような筋力, 筋パワーの発揮能力に おいて年齢が増すに従い大きくなると言えよう。これら のことから，14歳以降定期的にサッカーのトレーニング を継続することは, 下肢多関節動作で発揮されるパワー あるいは，それよりもトレーナビリティは低いもののス プリント能力に扔いても発達を促進する可能性があるこ とが示唆された。つまり同世代の一般人男子との比較結 果からそれらの増加は, プレ・ゴールデンエイジやゴー ルデンエイジといった神経系の発達が著しいとされる思
春期以前の年代から, ボールキック動作やジャンプ， ス プリント等の速い動作を行うことによる, サッカーの専 門的能力の発達の影響が大きいと考えられる。年の結果 として, 思春期以降のポストゴールデンエイジ（ジュニ アユース）年代からの増加率において, 同世代の一般人 男子と比較して, より14歳以降の増加率において大きな 差がみられたものと推察される。思春期スパート期にさ しかかるポストゴールデンエイジ以降の指導現場におけ るトレーニングでは, 脚筋力を高めるような指導を取り 入れていくことで, ボールキック動作やジャンプといっ たサッカーの専門的能力である下肢筋出力をより発達さ せることができると提言できる，また，ポストゴールデ ンエイジ以降に扔いて, 脚筋力を発達させる指導方法を 取り入れていくことで，一般的に増加率が低いとされる 走動作であるスプリント能力も向上させる可能性があ る. 特にスプリント能力は14歳以降, 他の項目と比較し て低い増加率を示したことから，プレ・ゴールデンエイ ジやゴールデンエイジに挄いてはスプリント能力向上の ために，特にピッチあるいはストライドの増加に主眼を おく指導を取り入れることが大切であると考えられ，そ のことによって思春期以降においても同世代の一般人男 子よりスプリント能力の増加率は高くなる可能性がある と言えよう。

$$
\text { まとめ }
$$

本研究では14歳から18歳までの育成年代のサッカー選 


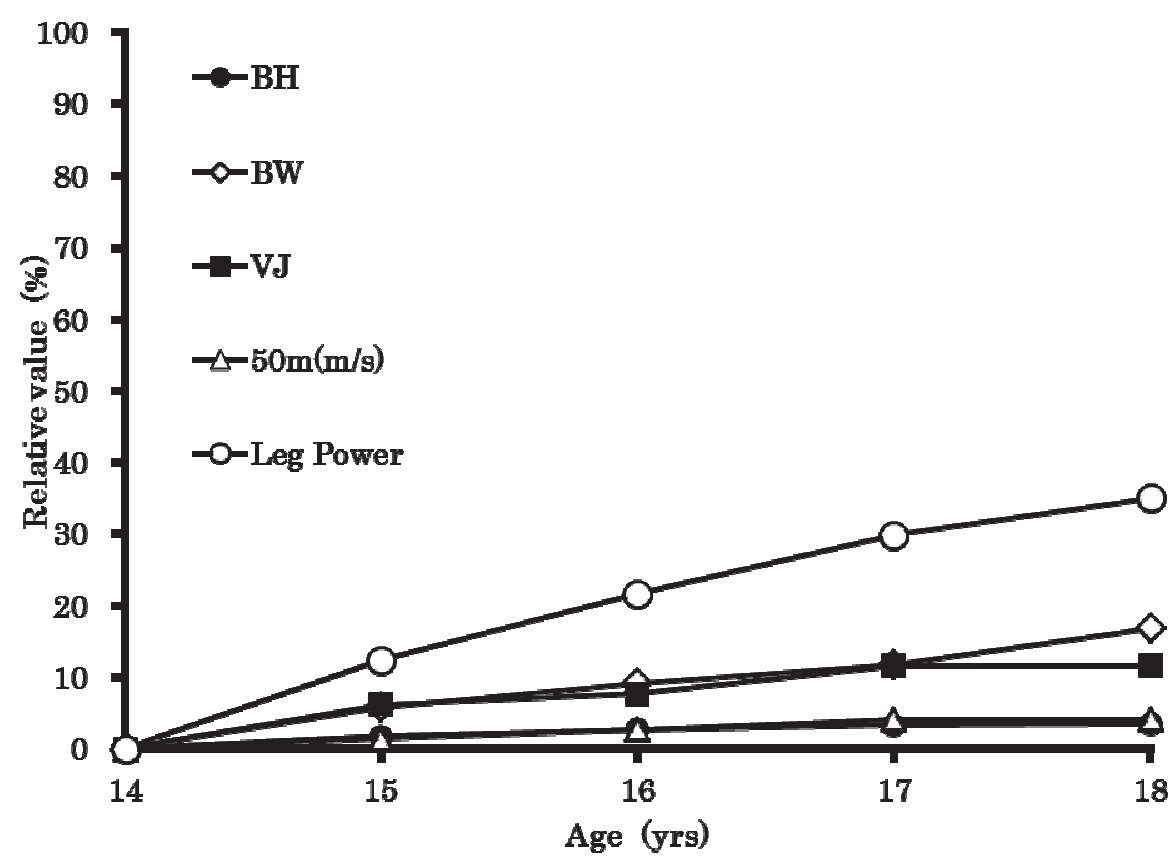

Fig 3. Relative values of development based on the values for 14 yrs as 100\% for BH, BW and lower-leg multi-joint power outputs in Japanese sedentary boys $\left(\right.$ standard values ${ }^{9)}$ ).

(BH : Body Height, BW : Body Weight, VJ : Vertical Jump, 50m (m/s): 50m-Sprint Velocity, Leg Power : Bilateral Leg Power)

手の身体組成と下肢多関節動作で発揮されるパワーおよ びスプリント能力について横断的に比較し，それぞれ形 態掞よび機能の増加率の特徵を検討することを目的とし た。その結果，14歳から18歳までの増加率を育成年代 のサッカー選手と同世代の一般人男子を比較した結果, サッカー選手は身長が2.3倍, 脚筋力は2.5倍, 跳躍高は 3 倍, スプリント能力は2.1倍高い值を示した. 14歳以 降のサッカー選手の脚伸展パワーや跳躍高のような筋 力, 筋パワーの発揮能力は年齢が増すに従い大きくなる ことが示されたと同時に，14歳以降の増加率が低いスプ リント能力においてもサッカーのトレーニングを継続す ることで，発達を促進する可能性があることが示唆され た.

\section{参 考 文 献}

1）財団法人日本サッカー協会・技術委員会：サッカー指 導教本2007, 財団法人日本サッカー協会, 東京, 26-33, 2007.

2) Malina RM, Boucahrd C (高石昌弘. 小林寛道監訳), 発 育 - 成熟 - 運動, 大修館書店, 東京, 3-9, 38-57, 216-232, 1994.

3）Bangsbo J (長谷川 裕, 安松幹展, 上田滋訳), 2育成年代 に打けるサッカー選手の身体的発達とトレーニング, ゲーム形式で鍛えるサッカーの体力トレーニング, 大 修館書店, 東京, 23-32, 2008.

4) Arnason A, Sigurdsson SB, Gudmundsson A, Holme I, Engebretsen L, Bahr R. Physical fitness, injuries, and Team performance in Soccer. Med Sci Sports Exerc
36 : 278-285, 2004.

5) Capranica L, Cama G, Fanton F, Tessitore A, Figura F. Force and power of preferred and non-preferred leg in young soccer players. $J$ Sports Med Phys Fitness $32:$ 358-363, 1992.

6) Balsom P. Evaluation of physical performance. In: Handbook of sports medicine Football (soccer) (Ekblom B. eds), IOC Medical Commission Publications Advisory Sub-Committee, Cambridge, Massachusetts, USA, 111-116, 1994.

7) Vescovia DJ, Mcguigan RM. Relationships between sprinting, agility, and jump ability in female athletes. $J$ Sports Sci 26 : 97-107, 2008.

8) Wisloff U, Castagna C, Helgerud J, Jones R, Hoff J. Strong correlation of maximal squat strength with sprint performance and vertical jump height in elite soccer players. Br J Sports Med 38 : 285-288, 2004.

9）首都大学東京体力標準值研究会編. 新 - 日本人の体 力標準值 II, 不昧堂出版, 東京, 21-26, 71-77, 172-175, 181-186, 199-202, 2007.

10）高橋流星, 小川幸三, 船渡和男 : レーザードップラー 方式距離計測装置によって得られた歩行運動の移動距 離と速度の正確性及び妥当性, 日本体育大学紀要, 40 : 35-42, 2010.

11) Gissis I, Papadopoulos C, Kalapotharakos I.V, Sotiropouls A, Komsis G, Manolopoulos E. Strength and speed characteristics of Elite, Subelite, and Recreational Young Soccer Players. Res. Sports Med 14 : 205-214, 2006.

12）星川佳広, 飯田朝美, 村松正隆, 中嶋由晴 : サッカー選手 に抢ける滕関節伸展・屈曲卜ルクと大腿部筋体積の年 
齢変化, 体育学研究, 52: 431-442, 2007.

13）涉川賢一, 星川佳広, スプリントトレーニングの計画と 実際，スプリントトレーニング 一速く走る・泳ぐ・ 滑るを科学する一, 日本トレーニング科学会 (編), 朝倉 出版, 東京, 138-144, 2009.

14）津越智雄, 浅井武：Jリーグサッカークラブにおける 上位カテゴリーへの選手選抜に関する横断的研究一 体力 - 運動能力を対象として -, 体育学研究, 55 : 565576, 2010.

15) Vaeyens R, Malina RM, Janssens M, Renterghem BV, Bourgois J, Vrijens J, and Philippaerts RM. A multidisciplinary selection model for youth soccer the Ghent Youth Soccer Project. Br J Sports Med 40 : 928-934, 2006.

16) Bangsbo J, Norregaard L, and Thorso F. Activity profile of competition soccer. Can J Sports Sci 16 : 110116, 1991.

17) Stolen TK, Chamari C, and Castagna U.Wisloff. Physiology of soccer. Sports Med 35 : 501-536, 2005.
18）財団法人日本サッカー協会技術委員会フィジカル フィットネスプロジェクト: 第2章 - 世界の指標 - , JFAフィジカル測定ガイドライン2006年版, 財団法人 日本サッカー協会編, 日本サッカー協会, 東京, 8-21, 2006.

19）安松幹展, 広瀬統一：フィジカルチェック結果からみた 日本人の選手の特徴: Journal of Training Science for Exercise and Sport, 22 : 307-312, 2010.

20）中屋敷真：サッカー選手の短距離疾走能力のトレーニ ング効果について, 第4回サッカー医・科学研究会報告 書, 財団法人日本サッカー協会, 東京, 104-109, 1984.

21）船渡和男: 筋収縮力の成長 - 加歯, 体育の科学, 38:431438, 1988.

22）船渡和男, トレーニングに及ぼす生物学的因子, トレー ニング科学ハンドブック, 朝倉書店, 東京, 305-322, 1996.

23）星川佳広 : 筋のつき方の男女差, Strength \& Conditioning Journal, 17, 2-10, 2010. 